\title{
Memory and History: A Comparison of the Past in Slovak Prose of the Post-200o Period
}

"Bože, ako ja nenávidím dejiny, ten vlastný životopis ludstva!" (God, how I hate history, the autobiography of humankind!)

Pavel Vilikovský (2005: 195)

We find a certain legitimising gesture in writing about the past. It may concern an individual or a society. The first case concerns subjective memory, the second concerns history as a different, impersonal type of memory. The present is always involved, as it determines the relation to what was and no longer is. The awareness of reality may be the source of sadness: the flow and the unstoppable nature of time, it may cause melancholy and futility. The opposite is a relief that what was has passed. Either mode is based on the insurmountable barrier between the past and present. However, the past may be perceived differently, as an understanding of the present as something that existed to enable what is now. This understanding of the past as the prehistory of the present was highlighted in Georg Lukács's book on the historical novel (Lukács 57).

Personal memory appears in different autobiographical genres and stylised biographical fiction draws on them. History is a domain of a historical genre, ${ }^{1}$ particularly the novel. These are two approaches which are both employed in a section Slovak prose of the past two decades.

Social demand articulated outside of the literary field inadvertently authenticates the legitimacy potential of prose depicting the past. After 1989, the social position of writers in Slovakia radically changed. While writers

1 René Bílik used this complex term in his book: Historický žáner v slovenskej próze. 
freed themselves of state control, literature was losing prestige and its social role. Literature was free but nobody demanded anything of it. The situation has remained virtually unchanged until the present time. If there are demands on literature coming from the public space, these mainly concern critical moments in Slovak history. ${ }^{2}$ This paper examines the questions: What are the possibilities and particularly what are the outcomes of such an approach to the past, and what are the alternatives of portraying the past in Slovak prose of the past two decades?

\section{Beginnings: The $1990 \mathrm{~s}$}

Compared to the current situation, literature of the 1990 focused largely on the present conditions shortly after changes in the social set-up, on the literary nature of writing and on the potential dispute in its authenticity or originality of the narrative. This was related to the incentives of postmodernism, which offered an agile ideological base attractive through its declared independence on ideology and which partly filled the ideological void after Marxism as an obligatory ideology. The focus of literature on itself was caused by external circumstances. Its loss of social prestige related to the break-up of structures through which the pre-1989 regime secured production of literature and a certain reputation of its authors and also the fact that after 1989 some non-literary functions were taken over by independent media or unregulated historical research. In this situation of disinterest in literature, the various interpretations of postmodernism, particularly in its popular version of "postmodernism as explained to children," attracted upcoming writers. The slogan about "the end of the grand narratives" was one of popular interpretations, and these "grand" narratives suddenly lost their legitimising function and subsequently their legitimacy. ${ }^{3}$ In this situation, there is no interest in an immediate rendering

2 An interview of the journalist Róbert Kotian with the prose writer Pavol Rankov is an example of this. The so-called normalisation and the period following the occupation of Czechoslovakia in August 1968 are regarded as periods noteworthy of literary depiction. Rankov highlights the cultivating and educational role of literature which was rejected after 1989 when he requires "representative writing that would show how it was during normalisation” (Kotian).

3 Jiří Pechar's introduction to the Czech translation of canonical texts by Jean-François Lyotard on postmodernism: "A current intellectual can only take a perspective devoid of piety towards the big stories whose main role is to deprive an individual of the right to narrate or act in the stories" is an apt reflection on the contemporary intellectual from countries which joined Europe towards the end of the 1980s (Pechar). 
of the past requiring broader legitimacy (immediacy or authenticity were perceived as constructs). Instead of writing that attempts to portray the past in new ways, writers produce prose showing the constructed nature of past writing. This prose is intertextual in nature, written in a form of parody, it does not reflect on the past, more on established literary and cultural forms articulating the past in the consciousness and subconsciousness of the society. The most notable prose of this kind is Peter Pištanek's (1960-2015) novel Mladý Dônč (Young Dônč). ${ }^{4}$ It subversively refers to several strata of Slovak literary tradition (critical realism of the turn of the nineteenth and twentieth centuries, the production novel as a representative genre of social realism or using the traditional cultural opposition of the city and village). It put a spotlight on past and present cultural and mental stereotypes, and it deconstructed the national myth using linguistic and literary techniques which contributed to forming this myth. The story is situated in the past but not within a particular historical period. The imaginary time in Pištanek's story feels mythical or rather pseudo-mythical and forms a bizarre tangle of the archaic and the modern. It does not reflect the reality of the past but of literature.

Compared to Pištanek, Igor Otčenáš (1956) took a seemingly reverse approach. In his book entitled Keby (If) ... with subtitle Rýchle dejiny budúcnosti Slovenska (A Quick History of the Future of Slovakia) (1998), he turns towards a specific historical period but only to contest it. The book aims to reflect on reality, not to learn from the past but to warn against it. The graphics and the style of narrative of If ... resemble textbooks of history; however, this format and use of alternative historical techniques are only means to parody and discredit the nationalistic historiography of the time. The amusing aspect of the narrative lies not only in the contrast between the historical reality and the author's mystification but also in the fact that reality and mystification can be expressed in the same way, stylistically and rhetorically. Pištanek's and Otčenášs questioning of historicism represents the typical perspective on history of the 1990s. This was not just the pre-1989 history most relevant Slovak prose writers distanced themselves from, but these were also historicising concepts which made claims for universal validity. The rift with history at the turn of the millennium was reflected in a trend towards portraying the past through personal and biographical memory. It followed from earlier motivations, which came to the pre-1989 Slovak literature from the periphery of the current literary field.

4 It was published under the same title as part of a collection of shorter prosaic pieces. 


\section{The Past Formed Through Memory}

Contesting historicity of the 1990 s was also related to returning to the topic of an individual against history or placing him/herself outside history. This subject was reflected in various forms of autobiographical writing, and in fiction it appeared as biographical stylisation. In comparison to the Czech literary context, this approach did not have a substantive tradition in Slovak literature, and before 1989 was used only by a small circle of dissidents outside of the official cultural production. The most notable of them was Dominik Tatarka (1913-1989), who was banned from publishing from 1970 as he opposed the 1968 occupation. He thus gave up on traditional fiction and wrote a series of autobiographical texts which he called "scribbles." The last of these he wrote was entitled Navrávačky (Recordings). At the turn of the 1980s, Tatarka posthumously returned to the public space. ${ }^{5}$ His work brought a new, open form of autobiographical narrating as a dialogue with oneself and one's past, which was not traditional in Slovakia and introduced a subject which disputed history. Tatarka's writing was important in that it established this form of writing as equal to the more traditional forms of writing.

The past reflected through memoir sources was also used in writings which were not explicitly autobiographical. Although the authors of these were not equally narrators in the sense of autobiographical writing, the biographical principal was used through different techniques, such using publicly known aspects of the author's biography used within the fictional narrative. The fact that the framework of the entirety of life of a character was used was more significant for constituting the biographical line of writing. This technique is typical of a section of Pavel Vilikovskýs (1941) prose. Vilikovský was an important Slovak writer of the turn of the 1980 os. His writing combined two significant periods in Slovak prose writing: reestablishment of modernism in the 1960 s associated with bringing back a subject which was "nationalised" by social realism of the previous decade and the Slovak version of the postmodern turn at the beginning of the 1990s. Both these periods are typically ahistorical personified by a character who stands outside of history or is its victim. Vilik-

5 Navrávačky (Recordings) were first published as samizdat in 1987 in Prague, in 1988 in Cologne by a West German publisher in exile and in Slovakia only after the author's death in Slovenské pohlady (Slovak Perspectives) journal (Tatarka). The text was written as an edited and authorised transcript of a tape-recorded interview based on an autobiographical memoir (the title refers to an oral form of telling stories, not always truthful). There are two published versions of Navrávačky. For more detail on this, please refer to: Matejov. 
ovský comes to terms with history as a collective narrative through grotesquely hyperbolic narrative, e.g. Večne je zelený ... (Ever Green Is ...) (1989, written in the 1970s). Personal memory situated within a family context is his alterative to history. This is nothing obvious; the author knows that what survived in this way is of rhapsodic, fragmented and uncertain nature. Vilikovskýs first prose of the biographical cycle ${ }^{6}$ entitled Kôñ na poschodí, slepec vo Vrábloch (A Horse Upstairs, a Blind Person in Vráble, published in a journal in 1988 and as a book in 1989) talks about a son who looks after his mother suffering from dementia, and shows memory as unreliable and deficient. In Vilikovsky's prose, the past is connected with the narrator's biography, as somebody born at the beginning of the 1940s (his first glimpses of memory reflect the end of the Second World War, then formative experiences of his boyhood and growing up). His past consists of a relatively small and steady group of his closest people, family (mother, prematurely dead father, older brother and housemaid). Vilikovskýs characters represent the past through connecting with those who are no longer alive. The need for the past is motived by emotions, a rational approach, and a need for accuracy and authenticity become irrelevant. Imagination and fantasy (which move on the boundary between reality and fiction) able to fill in void spaces in memory have a legitimate place in this type of reminiscing. Reading the correspondence of his parents before they were married, he imagines meeting his late father in a café as his contemporary. ${ }^{7}$ His reminiscing is constantly

6 This cycle is unique among Vilikovskýs prose in that certain constant features which repeat and vary, particularly in terms of the setting and characters (e.g. fatherless family), and also that it adopts the reminiscing mode of narrative. This writing cannot even be classified as biographical, as certain features can be identified in shorter prose together with short stories of different kind on different topics and of different nature. The first in this cycle is the novelette Kôn na poschodí, slepec vo Vrábloch (published in journal in 1988 and in 1989 as a book), his latest so far is RAJc je preč (The Paradise is Gone, 2018). There are other short stories which belong to this cycle, such as "Všetko, čo viem o stredoeurópanstve" (All I Know about Central-Europeanness) from a book entitled Krutý strojvodca (A Cruel Train Driver, 1996), "Gašpar, Melichar a Baltazárová" a "Pán spomienok" (The Master of Memories) from a book entitled Čarovný papagáj a iné gýče (A Magical Parrot and Other Kitsch) (2004) and partly a novelette "Na lavom brehu pamäti” (On the Left Bank of Memory) from a book entitled Prvá a posledná láska (The First and Last Love) (2013).

7 "I had to be careful, fantasy stumbled ... The problem was not even in that I could not have imagined him at twenty seven ... I could not imagine myself at twenty seven which was worse" (Vilikovský 2004b: 77-78.) 
interrupted by his older brother's specifying and correcting comments. ${ }^{8}$ Appropriating the past becomes a defence against interference with it. Compared to history as a collective and "nationalised" past after 1948, Vilikovský's characters "privatise" their past and do not want to share it with anybody and do not allow "editing" it by others. ${ }^{9}$ Corresponding memories with "reality" is not that crucial here, rather their uniqueness. This is compared to collective history requiring a more collective consensus, and power mechanisms and manipulation (an older person having a greater say) come to play. Reminiscence as a constituting element of the one reminiscing cannot become a subject of negotiation.

Vilikovský does not present extensive evocations of the past full of sense; he narrates about mechanisms which constitute the past as a defence of certain kind of memory. He adopts a reflective and problematising relation to the past and memory as its medium, which is uncertain and is not always just his own. Márius Kopcsay (1968) is the most notable upcoming writer of the turn of the $1990{ }^{10}{ }^{10}$ and has a slightly different attitude to the past than Vilikovský. He similarly writes about the past mediated through personal memory, particularly of his childhood and growing up. A typical character of Kopcsay's writing is an outsider. He experienced his childhood and youth during normalisation of the 1970 and 80 s and was not able to seize the opportunities presented after 1989. Kopcsay managed to capture life experiences of an individual typifying a generation who found himself in between two eras and periods of life: childhood (which will not come back) and adulthood (the demands of which he cannot cope, accept or come to terms with). He consistently preserves a child's perspective in relation to the past: respects the mental horizon of his character, does not amend it, and he does not use expressions and conceptualisations which would be inappropriate to the age of a child (when describing the period,

8 "The truth is that I have always felt deficient compared to my brother. Father was, of course, mutual but he spent more time with him ... I could live with that, not everybody can have it the same way. What annoyed me was that my brother always corrected me. I had only very few memories, three or four, as when father died, I was still young. And somebody kept crossing out and erasing even out of those ... there was always something that needed correcting" [emphasis added] (Vilikovský 2004b: 67).

9 "This was a memory, finally, finally a memory which belonged just to me. My own, I was its master, exclusive, supreme. I did not need to have it stamped off by anybody else" (Vilikovský 2004b: 87).

10 In this period, he published four books which determined the style of his subsequent writing. These include the novel Domov (Home) (2005) and a cycle of freely connected books of short stories Kritický deň (The Critical Day) (1998), Stratené roky (Lost Years) (2004), Zbytočný život (Pointless Life) (2006). 
he does not use terms such as totalitarianism or normalisation). He evokes life through a mosaic of concrete details typical of a period captured in a child's consciousness. These include means of transport (makes of cars-the Trabant, types of buses or trains ${ }^{11}$ ), names of places, objects of everyday use, and brands of products which were in limited supply. When describing the reality of the time, he avoids judgements of the regime. The adolescent character views "social realism" critically not because it deprives people of freedom and human rights but views it from a perspective of a consumer. He knows that products from the "capitalist" West, which are hard to get, ${ }^{12}$ are better than those he can buy in his country; he identifies with foreign, not local pop stars. ${ }^{13}$ Kopcsay portrays the past as if it is current, alive. Compared with Vilikovský's character who seeks "his own," unique memories, Kopcsay's character is rather a victim of an obsessive dominance of images supplied by his memory.

Neither Vilikovskýs, nor Kopcsay's past is a lost paradise; it does not portray an idyllic space where their characters were once happy. In situations where the author preserves a child's perspective, where the past is portrayed as the present, the childhood for the one who lives through it is no less problematic than any other stage of life. Regardless of this, the past as a memory takes on a certain idyllic aura resulting from current knowledge of the ignorance of that time. An adult knows what he, as a child, did not, could not, did not need or was forbidden to know about the world that surrounded him. The fact that his parents knew this on his behalf was enough. ${ }^{14}$ The option of not knowing is a privilege that, in the consciousness of others who are condemned to knowledge and cannot afford not to know, retrospectively adds an idyllic touch to

11 "They will be pulled by a diesel engine, there are only a few steam engines left ... They buy tickets, firm, small, square-shaped." (Kopcsay 161).

12 "He puts a Maxell cassette into its case ..." (Kopcsay 27).

13 "He longed to look like Roger Hodgson or Rick Davies from the band Supertramp but, at that age, his beard did not start growing .... He felt like one of the Supertramp band members in their double album photo cover from their concert" (Kopcsay 18, 26).

14 Compared to the 1950, during the Czechoslovak normalisation period, forgetting and erasing certain historical facts and personalities from the society's memory was preferable to a direct repression. The August 1968 occupation was one such erased event. Kopcsay's young hero's indifference to the occupation and presence of the Soviet Army in Czechoslovakia is not symptomatic in terms of values (morality) within the events of Kopcsay's piece but has a different characterisation function in relation to the era: "Do you know what they [Soviet soldiers] did in sixty eight? ... I do not know, as I was only born then, said Umelček. But your parents told you about it, said Rišo. No, they have not, said Umelček" (Kopcsay 24). 
a child's past. The not knowing is a perquisite of the completeness of a child's world, which disappears during adolescence. ${ }^{15}$ The option of not being in history is also a part of this privilege.

Three posthumous publications by Ján Rozner (1922-2006): Sedem dní do pohrebu (Seven Days before the Funeral) (2009), Noc po fronte (Night after the Front) (2010) a Výlet na Devin (A Trip to Devín) (2011) painted the most complex picture of the past in Slovak post-1989 literature. ${ }^{16}$ The author who emigrated in mid-1970s and lived in Munich as if belatedly returned to Slovak literature and culture, as his past presence was disputed. Between 1945 and the end of 1960s, he worked as a journalist, literary, theatre and film critic, translator, playwright and later as a scholar but not a prose writer. Similarly to many other Slovak writers and intellectuals, he was made unemployed and was banned from publishing at the beginning of the normalisation period, due to his critique of the August 1968 occupation. He belonged to the left-leaning intellectuals who supported communism after the Second World War (WWII) and contributed to establishing the Stalinist model in culture of the turn of the 1940s; and he joined those who favoured the liberalisation of the regime in the 1960s. His views were shared by many Slovak intellectuals two decade after the end of WWII. Rozner however differed from the majority because of his background (his mother was German and his father Jewish), and his desire to "belong" was viewed with suspicion by others. The Slovak cultural milieu where, despite the proclaimed "internationalism," the issue of nationality remained important, has never accepted him as their own. His identity was decided on by his father in the interwar period when he enrolled him into Slovak schools (his mother preferred German schools), but his difference blighted his entire life: "And so

15 Czech screen writer, director, playwright and prose writer Pavel Juráček (1935-1989), one of the founders of the Czechoslovak New Wave in film of the 1960s, who lost his job and was banned from writing during normalisation, noted down an interesting remark in his diary concerning childhood: "I cannot say whether I was happy then. I mean the typical talk about 'the escapes into carefree, happy world of the childhood years' in memoirs of classics. I have a feeling that I was not happy. One thing was certain however-I was hundred percent. I will never be as complete as then. My constant orientation towards childhood, my dependence on it, are therefore a longing for a lost completeness. I lived in a complete harmony with my dreams and imagination." (Juráček 333). Juráček’s perspective of childhood corresponds with Kopcsay’s. A certain degree of idyll can be ascribed to childhood, on condition that not happiness but completeness is regarded as its constitutive part.

16 Rozner wrote these books between the 1970 and his death. He published some parts of them in journals as shorter proses at the beginning of the $1990 \mathrm{os}$. 
I became a Slovak, my father thought. Most people in my life were not of that view. Let's say, unfortunately, but such is life" (Rozner 2010: 85). This position required a certain distance, with all his engagement in society at certain times of his life and represented a biographical prerequisite of a specific form of observation, which paid off in his prosaic work.

All three of Rozner's books of reminiscences can be read through two codes: as reminiscences which turn into memoirs in parts, as subjective testimonies and thus sources of information (which can be checked through other sources and open to corrections), and also as autonomous fiction of a particular genre (such as a novel, short story or sketch). The composition of each book is adapted to the basic characteristics of storytelling, reminiscing. What is important is not only the content of these reminiscences but also the mechanisms related to the process of reminiscing, i.e. the motivation of the reminiscing act.

Rozner's high level of literariness does not contradict the authenticity of his writing, but rather reinforces it. In his novel Seven Days before the Funeral, he employs the typological potential of the genre. The starting point of the noveldeath of the wife and circumstances of her funeral-initiates a socio-critical reflection on the era. Rozner and his wife Zora Jesenská ${ }^{17}$ belonged to the fairly large number of intellectuals banned by the regime in the early 1970s. The novel develops an ancient motive, revived by normalisation - the relation of the regime to its dead opponents, and its fear of these opponents. Zora Jesenskás funeral at the state cemetery in Martin was rather undignified. Many of her friends and acquaintances were scared to attend, the burial was conducted under the supervision of State Security, the officials did not want the funeral to turn

17 Zora Jesenská was a seminal personality of Slovak translation, particularly of Russian and Soviet literature. She was banned from publishing, including translations, for her public rejection of the August 1968 occupation and of normalisation. Her family and cultural background was significant in her relationship with Rozner. She originates from Martin, which was the centre of Slovak national and cultural movement from the mid-nineteenth century and she was the niece of Janko Jesenský, a classic of the interwar and pre-regime change Slovak literature. Compared to Rozner, she had very strong Slovak roots. Their relationship was also impacted by social inequality; Rozner was unacceptable for Jesenskás parents. These differences also reflect in the relations between both characters' home towns. Martin was a traditional national centre. Bratislava was multinational and became fully Slovak only after wwir. Only then Bratislava became a cultural centre and Martin became “yesterday's world.” Jesenská and Rozner also personify the conflict between the modern and traditional which shaped the development of Slovakia in the twentieth century. 
into an anti-regime demonstration. ${ }^{18}$ The book integrates several types of novel. It is an unconventional romantic novel through its outline of the characters' relationship. The autobiographical line of the narrative form a didactic novel, it is a story of a character shaped by circumstances and despite them: a story of growing up without a father, generationally symptomatic enchantment by avant-garde, story of ambitions which collide with adversity of the time, misfortune and also own limits. ${ }^{19}$

All three Rozner's books persuasively describe the space in which they are situated. The reminiscing is supported by places, particularly a town-interwar multicultural Bratislava lost its character after 1945. Rozner's prose exceptionally enriches the tradition, not particularly strong in Slovak literature, of "literarisation" of this town. This way, Rozner integrated the genre of geographically-cultural sketch in his reminiscing narrative and extended the effect of the memory function. It does not only relate to the subject but also the space as was defined by Aleida Assmann (see Assmanová) - the space of memories.

Rozner's reminiscing prose critiques historicity-it is paradoxical, from a perspective of somebody who once put his trust in history (he refers to History, clearly with irony). With a detached view he reliably reconstructs the post-war developments similar for many Central European intellectuals who put their trust in history at the cost of their own independence and integrity. ${ }^{20}$ Rozner

18 Jozef Felix, the leading Slovak literary critic and Romanist (translator of Dante), made a speech at the funeral. A member of the Secret Police asked to see the speech before it was made. Felix refused to give it to him. Felix was subsequently banned from teaching at university.

19 Rozner could not study during the war, as his Aryan origin was doubted. Together with his brother he was taken into a detention camp (which was a staging post on the way to a concentration camp). Their German mother, however, managed to get them out. After the war, he managed to save his mother from expulsion to Germany through his left-wing connections. His enchantment with the avant-garde, which he was intensely interested in from his secondary school years resulted in a piece which was possibly the first Slovak attempt at structural theory of film. The manuscript got lost at his Prague publisher in the post-war chaos. He long struggled with alcoholism, and went to a rehab a few times. The biggest rival to his artistic ambitions was his own indifference to himself.

20 There is one important objection to be made against Rozner's reminiscing; he pays most attention to parts of his life when he was a victim, times when he: "co-created History by chatting or rather discussing and sometimes writing ..." (Rozner 2011: 81).

He remembers the first half of the 1950 s with embarrassment and only selectively and in passing. 
is unique in that he was the first in Slovak literature who narrated this story in its complexity and literary persuasiveness. This includes motives which lead him to history, the need of a lonely person on the edge of society to belong somewhere. ${ }^{21}$

Rozner is close to Vilikovský in his aversion to history but differs in that he once wanted to be a part of it. The time that he reminisces about in his prose (mid-1930s to early 1970s) is the most dynamic part of modern Slovak history, which is up until now perceived as "live" and controversial. These external circumstances have contributed to the exceptional popularity of Rozner's books. They were read as first-class literature and also as testimonies. Personal memory perishes with those who held them, and the content of these reminiscences becomes a thematic repertoire of prosaic fiction for new generations of writers. They are left with what personal memory rejects and what is disputed by itsocial conceptualisations of the past through history. Fictionalisation of more modern Slovak history in prose has been on the rise over the past few years and the quality of this prose is uneven.

21 "I did not want to get under the wheels of History once again, to scuttle off and jump away from them, so that they did not knock me down and crush me, or did not leave me, behind with disinterest, as if I did not exist, as if I was not even worth crushing, they would happily be without me, and those on the train would look back at me with piercing, mocking, scornful sneers, which I once felt with my entire body at the top of the castle, an alien element ... unseen and unknown ... luckily something struck me back then and I agreed with History ... when looking at History as proven inevitability, I understood, it eventually struck me that my place is among a large hoard ... and so I mixed with it, attempted to keep pace with it, pushed to the front, just for god's sake not to stay behind, somewhere at the back and on the side where the whips lashed and dogs barked ... piles of dust were rising, I happily saw in the mirror that even I was covered in dust, the features of my face could barely be distinguished, I only uttered words and sentences started by others, I carefully instilled even the diction and intonation, I shouted those words and sentences so that others learnt them from me ..." (Rozner 2011: 90-91). Rozner's post-war engagement was motivated by what he had experienced during the war, his feeling that "History" saved him was justified. For him, the arrival of the Red Army really meant a salvation, a transition into a "new world" associated with adulthood and taking over responsibility. The History he called for arrived even in Bratislava, as the first Soviet soldiers got into the city in the spring of 1945: "I saw History in action, I saw history through from the fifth floor through my own eyes, the six to eight men who appeared from the murky dawn or fog rising up from the Danube, they were real and as though the only conquerors of this city, because I followed them with my own eyes ..." (Rozner 2010: 181). 


\section{Return into History}

In parallel with individual memory, the second source of rendering the past in literature is internalised historical memory of the society-history. This is rewriting of in some ways articulated, historicised past. This is a source of topics for epic fabulation. Slovak prose of the past decade attempts to make the past more attractive through this type of narrative, and to achieve this, it sometimes uses the means of adventure writing and this way comes closer to genre production. When fictionalising the past, it draws on the current historical memory. This socially acceptable, "politically correct" rendering of the past adjusted to the current range of values reinforces and legitimises the past.

Such an approach is typical of a part of Pavol Rankov's (1964) novel writing. He takes a perspective based on current values, he perceives the past as a space defined by time with the timeless good and evil fighting each other. The constructed nature of such writing where all aspects of the writing are adjusted to a set of ideals is prominent in Rankov's first novel of this kind, entitled Stalo sa prvého septembra (alebo inokedy) (It Happened on the First of September (or Whenever)) (2008). This is obvious in the choice of main characters when each represents one nationality (Slovak, Czech, Hungarian and Jewish). This is an approach which emphasises the value of multiculturalism in Central Europe, highlights it as being natural and positive. The novel's composition is based on a simple principle (each chapter relates to one year between 1938 and 1968), but this leads the author to overcomplicate the story. The semantic tension in the narrative benefits from the contrast between the ordinary and historical, the contrast between characters' relationships and the era which prevented those relationships from developing further. The life stories of Rankov's characters are so determined by history that they lose autonomy and serve only as prompts for outlining the most spectacular socio-political milestones. It is hard not to find an event which happened in Czechoslovakia and surrounding Central European countries during the given period of the 1930s that would not have affected the life of at least one of the characters. ${ }^{22}$

It is symptomatic for Rankov's interpretation of the past that the image of swimming baths on September $1,1938,{ }^{23}$ at the beginning of the book has

22 I remind readers only of the best known: Arbitration in Vienna, Hitler's satellites taking part in the Russian campaign, Slovak National Uprising (SNP), the extermination of Jews during the War, post-war expulsion of Hungarians, February 1948, the political processes of the 1950s, Budapest of 1956, building of the Berlin Wall, gradual liberalisation of the regime in the 1960s ending with August 1968.

23 This was a period of a few weeks before the Munich Agreement which was the first step in breaking up of the Czechoslovak Republic and an important prelude to wwII. 
an idyllic feel. It relates to a positive re-evaluation of the image of the interwar Czechoslovakia until 1989. It was supposed to be a space where an individual human existence could develop its full potential. This perception implicitly builds a connection to the image of the "golden era," the existence of something "pre-historical" or "without history" which ceases to exist when the bad history starts. ${ }^{24}$ According to Georg Lukasz, the historical novel is based on conscious continuity (the past is the pre-history of the present); this is pseudo-historicism (Lukács 30). Rankov and other Slovak prose writers of the last decade construct the period between the end of the 1930s and end of 1980 os as years of contrast to the ideal, as a "deviation," "historical error," in its effect legitimising the present.

Rankov's novel Legenda o jazyku (The Legend of Language) (2018) from the beginning of the 1970 follows on his book Stalo sa ... (It Happened ...), which finishes in 1968. The narrative is based on a parallel between the Middle Ages and normalisation developed through relation of a world power to religion and church. To express this simple analogy, the author uses a complicated fabulation. At the beginning of the 1970s, after a few days at university, four young non-conformist students of history realise that the official interpretation of the legend of the Saint John of Nepomuk is used by the regime as atheist propaganda. Attempting to find out the truth, they start their own investigation but the State Security gets involved and the story has a tragic ending-during interrogations, one of the students gets killed in the presence of his friend, who has a nervous breakdown as a result. The narrative is situated within the realm of the miracle, in terms of its genre and ideology, the novel is a hagiographyreinforced through the current social evaluation of the depicted period.

The historicising approach to a more modern past is not unusual in Slovak prose. An extensive attempt at a novel by Peter Krištúfek entitled Dom hluchého (The House of the Deaf Man) (2012) differs from Rankov's books in the narrator's perspective and reminiscing mode but is similar in one significant aspect: the current view of the past and trust in its social justification. The narrated situation reminiscing motivated by coming back home and re-evaluation-should bring the novel closer to prose based on personal memories. This stylisation is not employed in a trustworthy and consistent manner, as similar to Rankov, a historicising, detached perspective is used to express the conflict between memory and history. Both writers have selected a relatively long, almost identical period (Krištúfek from mid-1930s to the 1970s, with cross-over to the present); both of them approached the functional relation between the characters and era

24 This is an approach where the question "When does history start?" is interchangeable with "When things started getting worse?" without a change of meaning. 
in a similar manner. Both resolved the dilemma of whether to give preference to people or history by giving preference to history. Krištúfek's book and both Rankov's books are, at one level, a product of the so-called documentary research writing, a result of research across a range of sources (archives, newspapers from the time, internet, memoirs and others) and their subsequent fictionalisation. Both authors contrast the tragic history with the pre-historic "Golden Era" (interwar Czechoslovakia). Similar to Rankov, Krištúfek highlights the multi-ethnic nature of the then world. Books of both the authors are also related through their declared educational function: "Our national disease is a severe loss of memory," (Krištúfek 498) says Krištúfek's narrator, and the author seems to have the ambition to cure this disease. Prose about the past becomes an accessible means of balancing the information deficit concerning the past. Depicting the past through narrative is not original. It is fictionalisation of fantasy and related values which after 1989 became mainstream. This process concerned detachment from the past, self-legitimisation of new elites through distancing themselves from the past, which is typical of every radical social change. This gesture of distance is echoed in the historicising line of the current Slovak prose as a gesture legitimising the present. ${ }^{25}$

Rankov's and Krištúfek's narratives refer to but do not create; they refer to representations which have asserted themselves in the social conscience. They present a pre-established version of reality and with political correctness keep to a valid whole-of-society agreement about how things were. Both authors have made attempts at an extensive historical panorama stretched over a period of several decades. This attempt at complexity resulted in over-complex fabulation by Rankov and neutralisation of a personal perspective by Krištúfek. Silvester Lavrík (1964) took a different approach in his book Nedelné šachys Tisom (Sunday chess with Tiso) (2016), which is the most convincing historical novel

25 When G. Lukács talks about the crisis of historical prose after 1848, he mentions authors who run away from the "unbearable present" and disconnect it from the past: "The past, history does not organically relate to the present,, it forms its motionless opposite" (Lukács 240-241). This can also be related to Rankov's and Krištúfek's work, but their motivation is reverse to what Lukács talks about. He describes a part of Slovak prose as "intolerably" selected part of the past and contrasts them with the present and thus legitimises it. Lukács's understanding does not relate to historical prose, as the understanding of continuity as an important part of historical consciousness is missing and for their authors as "for writers after 1948 their continuity with the society's pre-history and the time they live and work in is not an immediate experience" (Lukács 250). 
in Slovak literature of the last few years. He focused on a shorter period and observed his chosen personal perspective; he was able to look at history from below, through the eyes of a non-historical, intellectually impaired character.

Compared to historiography, the prosaic discourse about the past is situated within fiction. This is not an area without obligations, but its truth has a different, not factual nature, its trustworthiness and persuasiveness are developed by different means. A person is the subject and the starting point of fictional narrative; it does not start from history but with the subject. In the novel Sunday Chess with Tiso, Lavrík managed to create the main character and narrator as a mediator of a journey into the past. The setting is similar to that of Plechový bubienok (The Tin Drum) by Günter Grass; the past is interpreted through the memories of the participant in the events who is interned in a psychiatric ward. Her mental disability prevents her from understanding events in the same way as most people understand them; she "does not understand" the conventional, agreed interpretation of events or does not want to understand them but remembers: "I did not understand much back then but I remembered everything” (Lavrík 145). The author effectively used one approach typical of modern prose, particularly a perspective of a narrator who is in some ways ruined or socially inferior (a child, mentally retarded, a mad person, eccentric or socially excluded person). These are people who are unable to work with agreed forms of understanding of reality, or they are able to step over or avoid it. ${ }^{26}$ The character coincidentally becomes the secretary to the wartime Slovak president (1939-1945), Jozef Tiso, one of the most controversial and discussed figures of more modern Slovak history, who up until now polarises society. Her depiction of the president is not an evaluation, just a convincing, situation "reproduction" of what she has seen and heard. The events are described

26 This approach was highlighted Franz K. Stanzel in relation to his theory of narrative: "The number of outsiders, doomed or disregarded who are being given this role in the modern novel (the role of a narrator, note by V. Barborík)-let's remind ourselves of Leopold Bloom, Josef K., Biberkopf, Meursault- "is remarkably high. The focus on a perspective and feelings of a mentally ill or demented person-such as Benjy in Faulkner's novel The Sound and the Fury or chief Bromden in Kesey's One Flew over the Cuckoo's Nest-should be viewed as a follow-on on the trend in using extreme means of representation. In all these cases the novelty effect is in moving the novel's perspective to that of an outsider; and this makes the reader see a known reality through different eyes" (Stanzel 20). The similarity between Lavrík's novel and The Tin Drum can be found even in the way it rejects the pressure of the surroundings: Grass's Oskár Matzerath by shouting and drumming, Lavrík's heroine by bouts of aggression and swearing. 
by a person who is not taken seriously by those who surround her. But this is exactly why she sees and hears what should have stayed hidden from the public. She perceives the world and statements literally, naively like a child, and this way she subverts the rhetorical dimension of the discourses of that period.

The linguistic side of the piece is an exceptional stylistic achievement within the context of current Slovak prose. The language is suited to the narrator, her exceptional memory and her inability to comprehend. The language mixes archaisms, regionalisms (words and also idioms), quotes and paraphrases of the ideological language of the propaganda, synthetic defects and clear child-like ability to depict what the society excludes. Lavrík's novel evokes also the setting in a trustworthy manner. A small town was then typical of the Slovak society of the era; it is based in Bánovce nad Bebravou. ${ }^{27}$ The visual part of the book further helps to set it in local reality. There is a map of the town from the era on the flyover of the book; the book contains photographs and copies of historical documents. The primary role of these sources is not documentary but subversive, as they are adapted to the fictional world of narrative.

In Sunday Chess with Tiso, a historical figure (the President of the Slovak Republic as a "historical subject") meets a character which is absent from history but gains the privilege of reminiscing as the narrator. Historical memory is not a starting point for fabulation about the past but a subject of a confrontation with personal memory. There is an encounter of these two types of memory also in Denisa Fulmekovás (1967) novel Konvália. Zakázaná láska Rudolfa Dilonga (Konvalia: The Forbidden Love of Rudolf Dilong) (2016). The narrative utilises real events from the war-time Slovak state, of which the public are partly aware. This is a love story between a poet, a Catholic priest Rudolf Dilong and a Jewish girl at a time when anti-Jewish laws in Slovakia had taken effect. Konvália is a type of prose about the past which combines memoir sources and fabulation. The novel uses personal, family history (the main characters were the author's grandparents). The narrative consists of two layers: factual, which uses documents from family, and official archives ${ }^{28}$ which are based on

27 Jozef Tiso was a Catholic priest and dean of the Bánovce parish. During his presidency, he regularly returned here from Bratislava to look after the parish and conduct his religious duties.

28 Dilong's letters to his daughter and mother of his child from exile are the most interesting. Rudolf Dilong was a leading figure of Catholic modernism, a line of interwar Slovak poetry which combined Christian spirituality and modern poetic expression. He was very productive; just between 1931 and 1945, he published 24 collections of poems of varied nature. Some were close to the avant-garde poetry of the time; some 
historical research, and fabulation, which make use of the romantic and adventurous potential of the reconstructed events. Although this is not fictional prose, the author employs methods which are typical of fiction, and this relates to her autobiographical approach. Her personal interest in the topic reflects in the literariness of the narrative, as she shapes the family history as a so-called powerful story, where she uses some conventional literary methods, tried and tested through tradition (such as the story is based on the topic of "forbidden love" at an unfavourable time). The book is situated on a boundary by its riven relation to the two mentioned types of memory: historical and personal. She does not draw a demarcation line between the past reflected through personal memory and societal memory, there is no direct rejection like with Vilikovský and Rozner. The poet Dilong, as one of the main characters, is already a part of history, literary history, and the author attempts to secure the same position for his partner, the author's grandmother, in the same literary-historical discourse. The author credits two collections from the beginning of the 1940s, which were published under a female pseudonym Ria Valé and which are up until now regarded as Dilong's collections, to his partner. This is a contrary gesture to what is typical of Rozner's and Vilikovskýs rendering of the past. While Rozner resigns from history and Vilikovský wants to avoid it, Fulmeková attempts to historicise her heroine and make her a part of the collective memory.

Every subjective portrayal of the past is a combination of inconsistent sources and different forms of mediation. Personal memory and historical memory are not the only two approaches to reflecting the past, rather opposite ends with a variety of their combination in between. The reason this author defined them as opposites when covering his particular topic was a need for a unifying starting point which would mark out the space for reflection and enable a coherent distinction between varied and imbalanced (in terms of their values) prosaic depictions of the past and help clarify their relations.

In the past 10 to 15 years, Slovak prose came back to depicting the past through history that was the object of manipulation until 1989 and forced out or rejected in the 1990s. This is not a full come-back to the traditional histor-

expressed the author's identification with the totalitarian regime of the wartime Slovak state. The poet's relationship with a Jewish girl was complicated by his being a Catholic priest and serving the totalitarian regime which declared its antisemitism (as a clergyman, he served in the Slovak Army which fought on the German side at the Eastern front). He knew the political elites of the time and through his interventions, he possibly saved his daughter and her mother from deportation to a concentration camp. After the war, he emigrated to South America via Italy, and later lived in the USA. 
ical novel and its functions; however, one important feature, legitimisation, is present in this writing: the negotiation of the representation of the past which would be acceptable according to present standards still takes place. This is even in the cases where the prosaic return to the past is in the form of a novel, and is based on active fabulation, so the result is a retrospective rather than a historical novel. ${ }^{29}$ A problematic presence of the past in personal or social memory is typical of this style of writing. The periods of history which the Slovak society is still coming to terms with and which are traumatic attract greatest interest. Slovak prose thus focuses on the more modern Slovak history of the twentieth century, particularly the period between the end of the 1930 and 1989. Despite the fact that access to this period is limited to mediation, developing a personal relationship to the subject is possible. An emotional connection is developed particularly in cases where personal family past is concerned.

In Slovak prose of the past twenty years, several basic approaches can be distinguished based on the relation between personal and historical memory. The past concerns exclusively subjective memory for Pavel Vilikovský and Márius Kopcsay. Historicising novels of Pavol Rankov and Peter Krištúfek represent the opposite pole; they exploit historical consciousness and thus fulfil the requirements of social order. This results in unsurprising, predictable outcomes, as these are included in the task. The author does not have to question what things looked like (e.g. What was normalisation like? related to a "normalisation" novel). The answer is known; he just needs to paint a picture which as closely as possible copies the current historical consciousness held in society. ${ }^{30}$ Such a taken-for-granted approach to the past is challenged in Ján

29 "A retrospective novel is a transitional form between a novel about the present and a historical novel. Although the novel depicts the past, the content is a part of the author's individual memory and the memory of the society (an ideal boundary between a historical and retrospective novel seems to be a gap of approximately 60 years, as beyond that span, the content becomes a closed history for the society)" (Mocná, Janáčková). Many of the novels the present author has discussed here are situated in a period more than sixty years ago, as is discussed in the above definition. The year 1938 was key for the majority of them, as a transition between a history-free idyll and tragic history. Although this is more than 80 years, this is still not a "closed past" and remains to be actively present in the societal and family memory as an open problem. It remains a subject of politicisation to the present day.

30 This approach does not exclude success; on the contrary, it is possibly a prerequisite for current literature. A Polish translation of Rankov's Stalo sa prvého septembra (alebo inokedy) (It happened on the first of September (or whenever)) was awarded the Central European Angelus prize for literature in 2014. 
Rozner's and Silvester Lavrík's prose. Despite their use of different foundations (autobiography vs fiction), their prose is connected through their perception of the past as a conflict between personal biography and history. The significance of Rozner's reminiscing prose was influenced by the author's circumstances; he was "part of history" for a while but was subsequently expelled from it-similar to Tatarka who viewed history from that perspective in his novel Recordings. This is different for Vilikovský and Kopcsay who are younger and did not make it into history.

Memory, whether personal in the form of reminiscences, or social in the form of history, is a means of making the past more accessible and bringing the past into the present. This form of mediation may either be accentuated or suppressed in prosaic interpretation. In the first case, the topic is not just the past but also the act of reminiscing, reflected as an uncertain and problematic undertaking closely connected with the opposite function of memory, forgetting. If personal memory is unreliable, the narrator who refers to it cannot be any different. At the end of the novel Seven Days before the Funeral, the only thing that connects the character to the past-the prerequisite of the narrative itself-is contested: "His own memory has betrayed him ... The memory which fabricates something or changes something in what it tries to remember ... something manipulates what it tries to recollect" (Rozner 307). The past which awaits us is uncertain; however this uncertainty may be a blessing for literature.

Translated by Pat Mertova

\section{| References}

Assmanová, Aleida. Prostory vzpomínání. Podoby a proměny kulturní pamèti.

(Translated from the German: Erinnerungsräume. Formen und Wandlungen des kulturellen Gedächtnisses). Trans. Jakub Flanderka, Světlana Ondroušková a Jiří Soukup. Praha: Karolinum, 2018.

Bílik, René. Historickýžáner v slovenskej próze. Bratislava: Kalligram - Ústav slovenskej literatúry SAV, 2008.

Chmel, Rudolf, ed. Slovník diel slovenskej literatúry 20. storočia. Bratislava: Kalligram - Ústav slovenskej literatúry sAv, 2006.

Fulmeková, Denisa. Konvália. Zakázaná láska Rudolfa Dilonga. Bratislava: Slovart, 2016. 
Juráček, Pavel. Deník (1959-1974). Praha: Národní filmový archiv, 2003.

Kopcsay, Márius. Stratené roky. Bratislava: L.C.A., 2004.

Kotian, Róbert "Mám rád nedôveryhodného rozprávača." Rozhovor s Pavlom

Rankovom (An Interview with Pavol Rankov). Magazín o knihách 3.12 (2018):

8-9.

Krištúfek, Peter. Dom hluchého. Bratislava: Marenčin PT, 2012.

Lavrík, Silvester. Nedelné šachy s Tisom. Bratislava: Dixit, 2016.

Lukács, György. Historický roman. (Translated from the German: Historische Roman). Trans. Július Albrecht. Bratislava: Tatran, 1976.

Matejov, Fedor "Navrávačky." Slovník diel slovenskej literatúry 20. storočia. Ed. Rudolf Chmel. Bratislava: Kalligram, Ústav slovenskej literatúry sAv, 2006. 445-449.

Mocná Dagmar, Janáčková Jaroslava. “Historický román” (Historical Novel). Encyklopedie literárních žánrů. (Encyclopedia of Literary Genres). Eds. Mocná Dagmar, Josef Peterka et al. Praha - Litomyšl: Paseka, 2004. 240.

Otčenáš, Igor. Keby...: Rýchle dejiny budúcnosti Slovenska. Bratislava: L.C.A., 1998.

Pechar, Jiří. "O postmodernismu, smyslu umění a právu na vlastní př́iběh.” Lyotard, Jean-François. O postmodernismu: Postmoderno vysvětlované dětem. Postmoderní situace. (Translated from the French: Le Post-Moderne expliqué aux enfants. La Condition postmoderne). Trans. Jiří Pechar. Praha: Filosofický ústav AV ČR, 1993. 5-11.

Pištanek, Peter. "Mladý Dônč." Mladý Dônč. Bratislava: Slovenský spisovatel, 1993. 39-92.

Rankov, Pavol. Stalo sa prvého septembra (alebo inokedy). Bratislava: Kalligram, 2008.

---. Legenda o jazyku. Bratislava: Slovart, 2018.

Rozner, Ján. Sedem dní do pohrebu. Bratislava: Marenčin PT, 2009.

---. Noc po fronte. Bratislava: Marenčin PT, 2010.

---. Výlet na Devín. Bratislava: Marenčin PT, 2011.

Stanzel, Franz K. Teorie vyprávění. (Translated from the German: Theorie des Erzählens). Trans. Jiří Stromšík. Praha: Odeon, 1988.

Tatarka, Dominik. "Navrávačky." Slovenské pohlady 105:17 (1989): 19-43; 106: 3 (1990): 6-37.

Vilikovský, Pavel. Kôň na poschodí, slepec vo Vrábloch. Bratislava: Smena, 1989a.

---. Večne je zelený ... Bratislava: Slovenský spisovatel', 1989 b.

---. “Gašpar, Melichar a Baltazárová.” Čarovný papagáj a iné gýče. Bratislava: Slovenský spisovatel, 2004a. 20-33.

---. "Pán spomienok." Čarovný papagáj a iné gýče. Bratislava: Slovenský spisovatel,' 2004b. 65-87. 
---. “V̌̌etko, čo viem o stredoeurópanstve." Prózy. Bratislava: Kalligram - Ústav slovenskej literatúry SAV, 2005. 191-197.

---. "Na lavom brehu pamäti." Prvá a posledná láska. Bratislava: Slovart, 2013. 5-135.

---. RAJc je preč. Bratislava: Petrus, 2018.

\section{| Abstrakt}

VLADIMÍR BARBORÍK

\section{Pamięć i historia. Ujęcia przeszłości w słowackiej prozie po $2000 \mathrm{r}$.}

Artykuł poświęcony jest sposobom, w jakich dwie podstawowe formy pamięci historyczna i indywidualna - przejawiają się w części słowackiej prozy ostatnich dwóch dziesięcioleci. Pamięć indywidualna stanowi podstawę różnych odmian autobiografii oraz nawiązującej do tego gatunku prozy stylizowanej na biografię. Pamięć historyczna zaś cechuje gatunki historyczne, przede wszystkim powieść. W latach dziewięćdziesiątych xx w. dominowały opisy współczesności, a historyzujące ujęcia przeszłości były poddawane radykalnej subwersji parodyzującej w prozach Petera Pištanka i Igora Otčenáša. Na początku nowego tysiąclecia ponownie pojawia się proza obrazująca i komentująca przeszłość. Bardziej sugestywne okazuje się pisanie o pamięci, które opiera się na jednostce znajdującej się wewnątrz historii lub poza nią. Znalazło ono zastosowanie w różnych formach pisarstwa autobiograficznego, w ramach literatury pięknej przyjęło zaś postać stylizacji biograficznej (np. Vilikovský, Kopcsay i Rozner). W ostatnich dziesięciu-piętnastu latach w literaturze słowackiej pojawiło się ponowne zainteresowanie historią, głównie tą sprzed roku 1989 (np. Rankov, Krištúfek i Lavrík), fałszowanej w literaturze sprzed 1989 r. i pomijanej lub wypieranej w latach dziewięćdziesiątych xx w. W tamtym czasie pamięć historyczna wychodziła naprzeciw oczekiwaniom społecznym. Wyjątkiem był Silvester Lavrík, który w swojej twórczości łączył dwa podstawowe podejścia do przeszłości (indywidualne i historyczne) w formie ich dialogu.

Słowa kluczowe: słowacka proza po 2000 r.; pamięć; historia; powieść historyczna; biografia; legitymizacja 


\section{| Abstract}

VLADIMÍR BARBORÍK

\section{Memory and History: A Comparison of the Past in Slovak Prose of the Post-20oo Period}

This study focuses on how two kinds of memory: historical and personal are reflected in a section of Slovak literature of the past two decades. A variety of autobiographical genres and biographically-stylised fictional prose draw on personal memory, and history, is the domain of historical genres, particularly the novel. After the 1990s, the present was deemed important and historical presentations of the past were parodied in the prose of Peter Pištanek and Igor Otčenáš. At the beginning of the new millennium, however, prose portraying and reflecting on the past reappeared. Memory-based writing which is concerned with an individual situated within history, or outside of it, is more persuasive. Memory-based writing is used in different forms of autobiographical writing: within fiction it takes a form of biographical stylisation (e.g. Vilikovský, Kopcsay and Rozner). In the past ten to fifteen years, there has been a renewed interest in history in Slovak literature, mainly in pre-1989 history (e.g. Rankov, Krištúfek and Lavrík), which had been mistreated in pre-1989 Slovak literature, and later there was no interest in it or it was even rejected in the 1990 .

During that time, historical memory was exploited to meet societal requirement. Silvester Lavrík was an exception-he was able to marry the two basic approaches to the past (personal history and historical) in a form of a dispute between them.

Keywords: Slovak prose after 2000; memory; history; historic genre; biography; legitimisation

\section{| About the Author}

Vladimír Barborík is Associate Professor; he graduated from the Faculty of Education in Nitra in 1992 (in Slovak Literature and Philosophy). Since 1992, he has worked at the Institute of Slovak Literature, Slovak Academy of Sciences in Bratislava. His research focuses on interwar and post-war Slovak literature (published monographs: Pavel Hrúz, 200o; Prozaik Gejza Vámoš, 2006 and Hladanie rozprávača: Prózy Vincenta Šikulu, 2014 and post-war literary life (with P. Darovec Mladá tvorba 1956-1970-1996; Časopis po čase, 1996 and V. Petrík Pohyb k nehybnosti. Literárny život od začiatku 6o. do konca 7o. rokov objektívom Antona Šmotláka, 2018). He co-authored several books such as interviews 
with V. Petrík Hladanie minulého času (2009). He was the editor of literary and cultural journals Dotyky, Kultúrny život, RAK a Slovenská literatúra. From 2008, he also teaches Slovak literature at the Catholic University in Ružomberok. E-mail: vladimir.barborik@savba.sk 
